\title{
IMPROVING STUDENTS' READING COMPREHENSION USING SCANNING TECHNIQUE
}

\author{
Edvieanto $^{1}$, Risman Munandar ${ }^{2}$, Aris Munandar ${ }^{3}$ \\ ${ }^{1}$ IKIP Siliwangi Bandung \\ ${ }^{2}$ IKIP Siliwangi Bandung \\ ${ }^{3}$ IKIP Siliwangi Bandung \\ ${ }^{1}$ viewpraja@gmail.com, ${ }^{2}$ rismandoang18@gmail.com,
}

\begin{abstract}
The research was conducted in SMK LuhurBaladikain West Bandung. Reading has become the important instrument in education especially in teaching and learning. Reading comprehension is the activity of constructing the meaning of a reading that has important funding in the process of education and the success of students in learning. The research aims to find out the benefit of using scanning technique, and the specific target to be achieved in this research is to prove scanning technique to improve students' reading comprehension. Output required of this research as a scientific publication in journal that have ISSN. The design of this research is Classroom Action Research (CAR). From the result of pre-test, we found that students' reading comprehension is under average, the score of pre-test is 59.00. After the implementation of scanning technique in every cycle, the students' reading comprehension were getting better, it can be seen in average of post-test score cycle 1 was 68.5 and cycle 2 was 79.00 . It can be concluded that scanning technique can improve students' reading comprehension.
\end{abstract}

Keyword: Reading comprehension, Scanning, CAR

\section{INRODUCTION}

The flow of information's in the present day so much variety. One way to get information is by reading. In the world of education, reading is one of the skills in the language and becomes the most important factor that must be mastered by the students. Therefore,researcher raised the reading variable to be thesubject of research. Ardakani and Laskharian (2015) state that "researchers do a lot of research with the object of reading ability more than ten".

Reading is the process of getting information by understanding the meaning of the text being read. It is supported by Ahmadi (2015), "The reading strategy of cognitive aspect understanding ability to play an active role in education process". In addition, Yun in Aydin Bulut (2017) states that "a student activity in acting, arguing, and building meaning in the process before reading at the time of reading-after reading. From these theories, it can be concluded that reading comprehension is the activity of constructing the meaning of reading, that has important funding in the process of education and the success of students in learning. 
Prastiti in Berbagiilmu (2013) states that, reading by goal and intent is divided into 5 types: intensive reading, reading techniques, quick reading, critical reading, and the art of reading". While the essential component of reading is divided into several components including:

1. Phonemic awareness is the smallest unit combined to form the language orally.

2. Phonics is a relationship for reading and spelling words.

3. Fluency is the smoothness in reading the text.

4. Vocabulary is a person's vocabulary related to reading comprehension.

5. Comprehension is a process of thinking that readers do in reading comprehension

Based on previous observation,students have not been able to understand the reading' presented. This is often a problem that continues to occur every year in the world of education in Indonesia, but the teacher is difficult to overcome this problem although teachers realize that reading is a major factor in the success of learning, although in every year the government always revises the curriculum. But the revision of the curriculum conducted by the government is not followed by qualified human resources in the implementation process this is one of the obstacles that must be addressed by the government in education. The specific difficulties associated with research on the lack of reading comprehension of students in the educational process are:

1. Internal factors: health problems, Abnormalities in organs, concentration, bad character, Awak (2015).

2. External factors: Lack of understanding of teachers in the mastery of the material, improper teaching methods, media textbooks is minimal, Wahdah (2015).

Factors mentioned above are the most important thing that must be improved. This must be done because the ability to read students becomes a gate in improving the quality of education.

There are two types of reading techniques: Skimming and Scanning. According to Rachmania, et al,.(2013), "from the results of research scanning techniques proved to improve students' reading ability and can save time". While the definition of reading by scanning techniques is how to find the main information contained in the text quickly. It is supported by Indriani (2016), "Scanning is a way of reading that is used to search information in text specifically by not paying attention to unwanted information". In addition, the learning process using scanning techniques according to Ruangguru (2016) has several steps including: 1) Paying attention to letters and numbers in the reading. 2) Pay attention to writing in italics or bold. 3) Researcher pay attention to keywords limited paragraph.Based on the ideas above, the researcher is interested in conducting a research entitled "IMPROVING STUDENTS' READING COMPREHENSION USING SCANNING TECHNIQUE."

\section{METHOD}

This research was held in December 2017 at the first grade students in SMK LuhurBaladika Batujajar, Bandung in the academic year of 2018/2019 with the number of subjects are 40 students, which. Thus, this research is a reflection of the implementation and development of methods from the point of view of expert with the aim to improve students' reading ability of the contents of English reading text.

This research was held in December 2017 at the first grade students in SMK LuhurBaladika Batujajar, Bandung in the academic year of 2018/2019 with the number of subjects are 40 students, which. Thus, this research is a reflection of the implementation and development of methods from the point of view of expert with the aim to improve students' reading ability of the 
contents of English reading text.The type of research conducted is classroom action research method. There are some steps of this research:

1. Research planning, that includes seeking syllabus, studying it and making a lesson plan in accordancewith the syllabus.

2. Implementation of teaching and learning process of reading students using scanning technique adapted to the lesson plan, in this activity the teacher explains the meaning of readingwithscanning technique then the teacher distributed a narrative text and the students are given a written test in accordance with the text read by each student.

3. Analysis and final report. In this section the researchersmake an analysis of all the information obtained during the research process and present it in the results of final report.

\section{RESEARCH CYCLES}
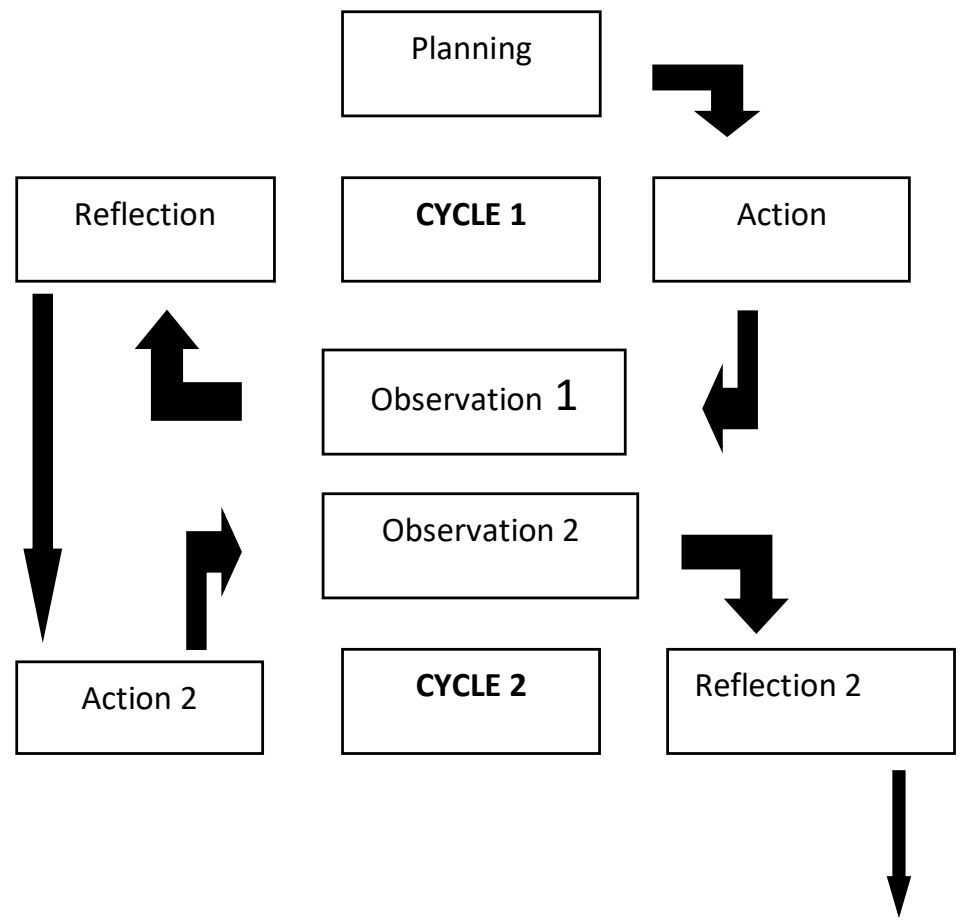

If there are any unresolved issues

Figure 1. Classroom Action Research Cycles（SuharsimiArikunto 2007)

In the above cycle there are several processes that are done among them

1. Cycle 1

a. Planning, at this stage the researcher designing the learning process that will be done Based on the results of the identification problem during data collection.

b. Action, after doing the planning, the researcher did the classroom teaching using scanning technique in accordance with the action plan prepared by the researcher.

c. Observation, at this stage the researchers make detailed observations on the activities in the classroom ranging from teachers, student reactions, through scanning techniques are taught in order to identify new problems and improve it, this process is done simultaneously between observers and teachers.

d. Reflection, at this stage the teacher gives a test to see the results of learning using scanning techniques to see things that are still weak to do improvements on the next cycle or things that are considered enough. 


\section{Cycle 2}

a. Action 2, in this phase the researchers do the learning after making improvements to the results of observations at cycle 1

b. Observation 2, at this stage the researchers make observations on things that are considered still less in the process of teaching and learning using Scanning techniques.

c. Reflection, Similar to cycle 1 this stage the researchers provide a test in writing and make an analysis of learning outcomes that have been done on cycle 1 and cycle 2

The implementation of this research is carried out with a recurring cycle, that each cycle containing the planning, the implementation of the action, the analysis and the report. Similarly, the next cycle is done on the basis of the cycle that has been done to make improvements from the weakness of the previous cycle. The techniqueue of data retrieval in this research is done by as follows:

1. Observation. This method aims to see and analyze the learning process that students do every day. Observations made by researchers during the classroom research process involving students and teachers, the results of the observations describe the situation in the classroom during the process of teaching and learning activities, mutual interaction between teachers and students, and assessment of the implementation of scanning techniques conducted by teachers.

2. Interview. This method is aimed to analyze information obtained from some teachers in reading comprehension learning in English text. From the results of interviews conducted to several teachers we can conclude that, teachers have done the implementation of learning in accordance with Syllabus and Lesson Plan with learning methods tailored to the material of teaching, but the results far from the desired target and the average student in absorbing information given by teachers can be categorized as low. As expressed by teachers, the lack of facilities and infrastructure owned by schools and the lack of faculty, forcing schools to recruit inexperienced teachers.

3. Fill out the questioners by students. It aims to see students' interest in reading learning. From the results of questioner filling done by students, then we can conclude that students have low reading motivation, which affects the low ability of students in understanding a reading and other impact is difficult for students to catch up learning especially in terms of reading.

4. Test and assessment. In this phase assessment is obtained from the learning process of students before treatment and after treatment. The purpose of the test itself is to determine the ability of students to capture information provided by the teacher, this process also to determine the planning of learning and evaluate what should be improved. The above statement is supported by Jones(2005) "The results of the study can be known from the test scores made after the learning process that illustrates the progress of students". The formula to find the mean as stated by Ngadiso (2013: 5-7) is follows:

$$
\begin{aligned}
& \mathrm{M}=\frac{\sum \mathrm{X}}{\mathrm{N}} \\
& \mathrm{M} \quad=\text { Mean score } \\
& \begin{array}{ll}
\mathrm{N} X & =\text { Total score } \\
& =\text { Total students }
\end{array}
\end{aligned}
$$

If the mean score increases, the students' reading comprehension is considered improving.

\section{RESULT AND DISCUSSION \\ Results}

The result of this research are describe as follow:

\section{Cycle 1}

a. Planning : Read narrative text, discuss with a friend and work on the related text

b. Action 1: the teacher explains about reading technique by scanning, the 
Students read narrative text (Malin Kundang) by scanning technique then discuss the main idea in the reading, Test.

\section{c. Observation :}

Achieved

1. Motivations, student motivation is good enough when reading a fairy tale (Malin Kundang)

2. student interaction, interaction between classmates and questions and answers with related teachers reading

Not Achieved

1. Vocabulary, less vocabulary possessed by students resulted in inhibition of material to be delivered

2. The condition of the less conducive class during the discussion makes it difficult for the teacher to explain the material

3. Grammar, students do not know the grammar form contained in narrative text.

d. Reflection :Maintained (Motivations, interaction), Improvement (Vocabulary, Grammar, The class situation)

\section{Cycle 2}

a. Planning : reading narrative texts to improve vocabulary, reading comprehension and discuss the related text

b. Action 1: Students read the narrative text (Si kancil) by Scanning technique, Discuss the main idea about text, test

c. Observation: Improving vocabulary and reading comprehension, teachers are better at maintaining classroom conditions in learning activities teachers deliver material well and quickly arrested by students.

d. Reflection: Positive (Motivation, interaction, feedback, increase vocabulary), Negative (lack of grammar, it takes a lot of reading practice).

From all research poses, in an effort to improve reading comprehension through scanning technique, it can be concluded that students' reading comprehension increases. Scanning technique is considered to motivate students and increase student interest in reading, because this technique is considered fun and does not make bored and help students in understanding the contents of reading. Significant boost capability can be proved by comparison of pre-test and post-test values, the comparison can be seen from the table below.

Table 1.Pre-test average Score

\begin{tabular}{clc}
\hline No & Explanation & Score \\
\hline 1 & The highest score & 66.00 \\
2 & The lowest score & 52.00 \\
3 & The average score & 59.00 \\
\hline
\end{tabular}

Table 2.Pre-test average Score of reading elements

\begin{tabular}{lll}
\hline No & Reading Elements & Score \\
\hline 1 & Main idea & 61.70 \\
2 & facts & 59.82 \\
3 & Context & 59.57 \\
4 & Sequence & 59.90 \\
5 & Inference & 59.92 \\
6 & Conclusion & 58.52 \\
\hline
\end{tabular}

The average score 
Table 3.Post-test average Score of cycle 1

\begin{tabular}{ccc}
\hline No & Explanation & Score \\
\hline 1 & The highest score & 74.00 \\
2 & The lowest score & 63.00 \\
3 & The average score & 68.50 \\
\hline
\end{tabular}

Table 4.Post-test average Score of reading elements of cycle 1

\begin{tabular}{lll}
\hline No & Reading Elements & Score \\
\hline 1 & Main idea & 67.37 \\
2 & facts & 66.37 \\
3 & Context & 66.00 \\
4 & Sequence & 65.85 \\
5 & Inference & 65.92 \\
6 & Conclusion & 64.92 \\
\hline & & 66.07 \\
\hline
\end{tabular}

Table 5.Post-test average Score of cycle 2

\begin{tabular}{ccc}
\hline No & Explanation & Score \\
\hline 1 & The highest score & 84.00 \\
2 & The lowest score & 74.00 \\
3 & The average score & 79.00 \\
\hline
\end{tabular}

Table 6.Post-test average Score of reading elements of cycle 2

\begin{tabular}{lll}
\hline No & Reading Elements & Score \\
\hline 1 & Main idea & 79.67 \\
2 & facts & 79.25 \\
3 & Context & 79.15 \\
4 & Sequence & 79.00 \\
5 & Inference & 79.12 \\
6 & Conclusion & 79.20 \\
\hline \multicolumn{4}{c}{ The average score } & 79.23 \\
\hline \multicolumn{4}{c}{ Table 7.Post-test average Score of cycle 1 and 2 } \\
\hline \multicolumn{4}{c}{ Explanation } \\
\hline 2 & The highest score \\
3 & The lowest score & 79.00 \\
& The average score & 73.50 \\
\hline
\end{tabular}




\section{DISCUSSION}

From the results of the research, it can be concluded that students lack the ability to comprehend reading and it can be seen from the results of data collection during research such as, Observation, Interview, questioner, and test. Of all these instruments illustrate the factors that cause low reading comprehension ability of students. Thus, researchers try to improve students' reading comprehension using scanning technique.

\section{CONCLUSSION}

Based on the result of the research. The researchers drawn conclusions as follows:

1. The use of scanning technique can improve the students' reading comprehension.

2. Scanning technique is easy to apply for students and teachers in teaching and learning activities especially in reading comprehension.

3. Teaching process using scanning technique can save in time.

4. Students are expected to easily absorb information from other subjects.

5. With the scanning technique of increasing student activeness, it can be seen from the feedback of students in each answer question.

\section{ACKNOWLEDGMENTS}

Gratitude Alhamdulillah always the writer pray to the presence of Allah SWT. the loving and compassionate, which provides all the great pleasures, favors of faith, health and strength in the preparation of this article. Sholawat and greetings are always poured out to the role model of all time, Prophet Muhammad, along with his family, friends, and his followers.

On this occasion, the authors express their greatest gratitude and the highest appreciation to Ms. AseptianaParmawati, M.Pd as Supervising Lecturer, on the sidelines of her routine always take the time to give guidance, encouragement, suggestion and direction since research plan until the completion of writing this article. And to other parties who have been so helpful but cannot be mentioned one by one. may Allah reward all his merits and good deeds. Hopefully this article can be Usefulfor education.

\section{REFERENCES}

Ahmadi, at al. (2013).The Importance ofMetacognitive Reading Strategy Awareness in Reading Comprehension.Canadian Center of Science and Education, vol 6. No10.

Ardakani, Laskharian. (2015). Using mindMapping Strategy to Improve Reading Comprehension Ability to Intermediate Iranian Student. Science Journal (CSJ), vol 36. No:3.

Arikunto, Suharsimi. 2007. Penelitian indaka kelas. Jakarta: PT BumiAksara.

Indriani. 2016. Improving Students' ReadingComprehension Through Scanning Technique. Skripsi. Lampung University.

Jones. 2005. Assessment for Learning. London: Learning and skills Development Agency. Moleong in Maryuni.(2014, p4).Peningkatan Kemampuan Membaca Melalui Permainan Menyusun Kata PadaSiswa Kelas I SDN Inpres 5 Birobuli.Jurnal Kreatif Tadulako Vol.4 No10.

Ngadiso .(2013). Statistic MateriMatakuliah Pascasarjana UNS Surakarta.

Prastiti in Berbagiilmu.(2006).Macam-macamTeknik Membaca.Available at: khumairohnabillaglenon.blogspot.co.id/2013/09/macam-macam-teknik-membaca.html?m=1. Retrieved on January 22th, 2018.

Rachmania, et al., 2013.The effectivenessof Scanning Technique in Increasing Students' Reading Comprehension Achievement. Available at: http://download.portalgaruda.org/article.php. Retrieved on February 25, 2018

Ruangguru. 2016. Skimming danScanning:RahasiaBelajardenganMembacaCepat. Available at: https://www.google.co.id/amp/s/blog.ruangguru.com/skimming-dan-scanning-membaca cepat\%fhs amp=true. Retrieved on January 21, 2018.

UdaAwak. 2015. MengenalFaktorInterrnalKesulitanBelajarSiswa. Available at: https://www.matrapendidikan.com /2015/11/mengenal-faktor-internal-kesulitan.html?m=1 
164 Edvieanto-1, Munandar-2, Munandar-3, Improving Students' Reading Comprehension ...

Retrieved on January 21th, 2018.

Wahdah.(2015). Faktor-FaktorKesulitanSiswaDalamMembacaTeksBahasa Arab. Available at: http://repository.upi.edu/21331/ Retrieved on January 21th, 2018.

Yun in AydinBulut. (2017). Improving $4^{\text {th }}$ Grade Primary School Students' Reading Comprehension Skills. Universal Journal of Educational Research, 5(1): 23-30, 2017. 